\title{
A review of the international trade in amphibians: the types, levels and dynamics of trade in CITES-listed species
}

\author{
Angus I. Carpenter, Franco Andreone \\ Robin D. Moore and Richard A. Griffiths
}

\begin{abstract}
Globally, amphibians face many potential threats, including international trade. However, there is a lack of knowledge regarding the types, levels and dynamics of the amphibian trade at the global scale. This study reviewed the trade in CITES-listed species between 1976 and 2007. Four main trade groups (eggs, skins, meat and individuals) were identified. Trade in amphibian leather focused on Hoplobatrachus tigerinus (5,572 individuals), whereas trade in eggs focused on Ambystoma mexicanum (6,027 eggs). However, for the entire study period (1976-2007), trade in skins and eggs was small compared with trade in meat and live animals. The meat trade was estimated to be worth $>$ USD 111 million, whereas the trade in live animals was estimated to be worth $>$ USD 11.5 million in only three of the genera involved. Trade dynamics have changed as a result of changes in legislation, such as a ban on $H$. tigerinus exports from Bangladesh for meat. Within the live trade 22 species categorized as either Critically Endangered or Endangered were traded during the study period, and these require greater attention. International trade and potential conservation benefits are affected by countries supplying captive-bred individuals to their domestic markets as this trade goes unrecorded. However, this study only investigated trade in species listed by CITES, and other species may comprise a significant additional component of international trade. The trade in amphibians is dynamic, and changes in both the types of trade and the species concerned were identified over the study period. Conservation concerns have multiplied from issues concerning population depletions to include indirect impacts associated with disease, predation and competition, which requires a reappraisal of data capture and reporting.
\end{abstract}

Keywords Amphibians, amphibian conservation, bushmeat, CITES, pet trade, wildlife trade

\footnotetext{
ANGUS I. CARPENTER (Corresponding author) Centre of Ecology, Evolution and Conservation, School of Environmental Sciences, University of East Anglia, Norwich, NR4 7TJ, UK. E-mail carpenter.angus@gmail.com

Franco Andreone Amphibian Specialist Group/Museo Regionale di Scienze Naturali, Torino, Italy

RobIN D. Moore Conservation International, Arlington, VA, USA

RICHARD A. GRIFFITHS Durrell Institute of Conservation and Ecology, School of Anthropology and Conservation, University of Kent, Canterbury, UK

Received 12 February 2012. Revision requested 13 August 2012.

Accepted 16 November 2012. First published online 10 June 2014.
}

\section{Introduction}

mphibians are currently facing a global extinction

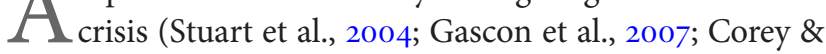
Waite, 2008; Wake \& Vredenberg, 2008; Warkentin et al., 2009). Seven major drivers of extinction have been identified (Gibbons et al., 2000), including conventional threats such as habitat destruction and introduced species (and synergies between them), as well as commercial trade.

Although the Global Amphibian Assessment (2008) provides an overall review of conservation status, most other studies focus on distribution patterns (Brooks et al., 2007), attempting to predict future declines (Bielby et al., 2008) and regional patterns (Andreone et al., 2005, 2008; Burgess et al., 2007). Few studies have reviewed the trade in amphibians from a global perspective. For example, previous studies have concentrated on the meat (frogs' legs) trade (Oza, 1990; Veith et al., 2000; Warkentin et al., 2009) or on the live trade of amphibians from a single source country destined for the international pet market (Carpenter et al., 2007; Carpenter \& Robson, 2008). There is a lack of understanding of the level and temporal dynamics of the amphibian trade at the global scale (Stuart et al., 2004). Following the amphibian conservation summit of the IUCN Species Survival Commission, Gascon et al. (2007) highlighted six priority areas: (1) sustainable use, (2) species action plans, (3) trade monitoring, (4) commercial breeding/raising, (5) law and enforcement, and (6) awareness raising. A review of the trade would facilitate better planning and efficacy of efforts by conservation organizations as well as providing more general knowledge regarding the international trade in amphibians (Schlaepfer et al., 2005; Stuart, 2007).

Here we provide a comprehensive review of the global trade in CITES-listed amphibian species, to establish a platform of knowledge. We aim to identify the countries involved and the types, levels and complexities of the international trade in amphibians. Specifically, we aim to answer the following questions: (1) What are the types of commercial trade conducted? (2) What are the levels and dynamics of the trade? (3) Which are the major source and destination countries participating in the trade? (4) Which species feature significantly in the types of trade conducted? 


\section{Methods}

CITES monitors the international trade in amphibian species listed in its Appendices (Rosser et al., 2001). Each CITES member state must submit an annual report with details of their international trade in CITES-listed species, and these reports are submitted via a nominated CITES management authority (MA). The data from each report are collated, uploaded and held on the CITES trade database by the United Nations Environment Programme World Conservation Monitoring Centre (CITES, 2010).

CITES uses codes under categories within these data sets to indicate where animals were sourced, the purpose of the trade and the form in which the item was traded (CITES, 2004). CITES also uses standardized nomenclature in an effort to keep up to date with taxonomic changes (CITES, 2009a). However, there are occasions when CITES is conservative in its adoption of changes in nomenclature. Typical examples of nomenclature variation are exhibited when the literature uses different names, such as the genera Rana and Lithobates, interchangeably or uses names other than those used within the CITES trade database (e.g. the strawberry poison dart frog is named Dendrobates pumilio in the CITES database and Oophaga pumilio on the IUCN Red List). Furthermore, CITES data sets may include species that are not listed in CITES Appendices because regional or national legislation requires the collection and reporting of the trade; for example, Lithobates catesbeianus has been listed, since 1997, on Annex B of the European Commission CITES Regulations because of the risks it poses to native biodiversity (Altherr et al., 2011).

This review utilizes these reported data for trade in amphibians from the CITES database. Although annual reports should be submitted in October of each year, some reports are added at other times of the year. As a result of delays in reporting, data for the 2 years preceding the year of collation may not reflect the total trade. Therefore, the date on which data are downloaded and collated influences the timeframe for analysis. The data set used in this review, spanning 1976-2007, was collated in August 2008. It includes all trade categories within 'terms', which describes the type of trade conducted (e.g. eggs, meat, live), 'source', from where the individuals were derived (e.g. wild, captive bred, ranched) and 'purpose', the reason for the trade event (e.g. commercial, education, science; CITES, 2009b). Data downloaded from CITES come in both an import and export data set. However, after an initial comparison of terms to review the types of trade conducted in amphibians, only the net import data were used in the analysis of levels and dynamics of the trade because of the variations and caveats within the CITES trade data set. For greater detail on the rationale for this see Harwood (1999), Carpenter (2003) and the World Conservation Monitoring Centre's guide to interpreting the CITES database (CITES, 2010).
TABLE 1 The arbitrarily defined groups (in italics) and trade terms recorded for the reported import trade, collated in August 2008, and the amounts of trade reported under each group/term (UNEPWCMC, 2010).

\begin{tabular}{ll}
\hline Group (trade term/s) & Total \\
\hline Individuals (bodies, live animals) & 482,292 \\
Meat (kg) & $>26$ million \\
Skins (shoes, skins, leather, leather products) & 5,790 \\
Derivatives & 217 \\
Eggs (eggs, live eggs) & 6,152 \\
Skeletons & 1 \\
Skulls & 2 \\
Unspecified & 17 \\
\hline
\end{tabular}

\section{Results}

For 1976-2007 14 'terms' were reported in the import data set compared to 11 in the export data set, which are indicative of the different types of trade being conducted. Five 'terms' were reported in both the import and export data sets (bodies, derivatives of amphibians, live individuals, meat and specimens); however, the levels of trade reported under each of these terms were considerably lower in the import data set, an observation consistent with other studies (Harwood, 1999; Carpenter et al., 2004, 2005). Using just the import data set, 'terms' covering similar types of trade were grouped into a single category and the values of trade reported for each 'term' accumulated (Table 1 ). This resulted in four groupings: (1) eggs, (2) skins, (3) meat, and (4) live animals (Table 1 ).

\section{Eggs}

The import of eggs was recorded for Ambystoma mexicanum $(6,027 ; 98 \%)$ and Oophaga pumilio $(125 ; 2 \%)$ only (Table 1). Of the 13 reported trading events for A. mexicanum, 10 were sourced from the USA and two from Canada, and one consignment from Mexico was confiscated/seized in 2003. All the USA-sourced trade, 5,577 eggs (91\% of the total reported), was recorded under the source code 'C' (Animals bred in captivity in accordance with Resolution Conf. 10.16 (Rev.); CITES, 2009b). Eleven of the 13 trading events provided a 'purpose' code, of which nine $(82 \%)$ were 'scientific' ('S') and two, both reported from Canada, were for 'commercial activity' (' $T$ ').

Trade in O. pumilio was reported twice, with both trading events, in $1997(n=25)$ and $1999(n=100)$, being sourced from wild populations, exported from Costa Rica and imported by the USA. No 'purpose' codes were reported for either trade event.

\section{Skins}

The reported levels of trade in amphibian skins/leather and/or skin products (Table 1) were recorded for four 


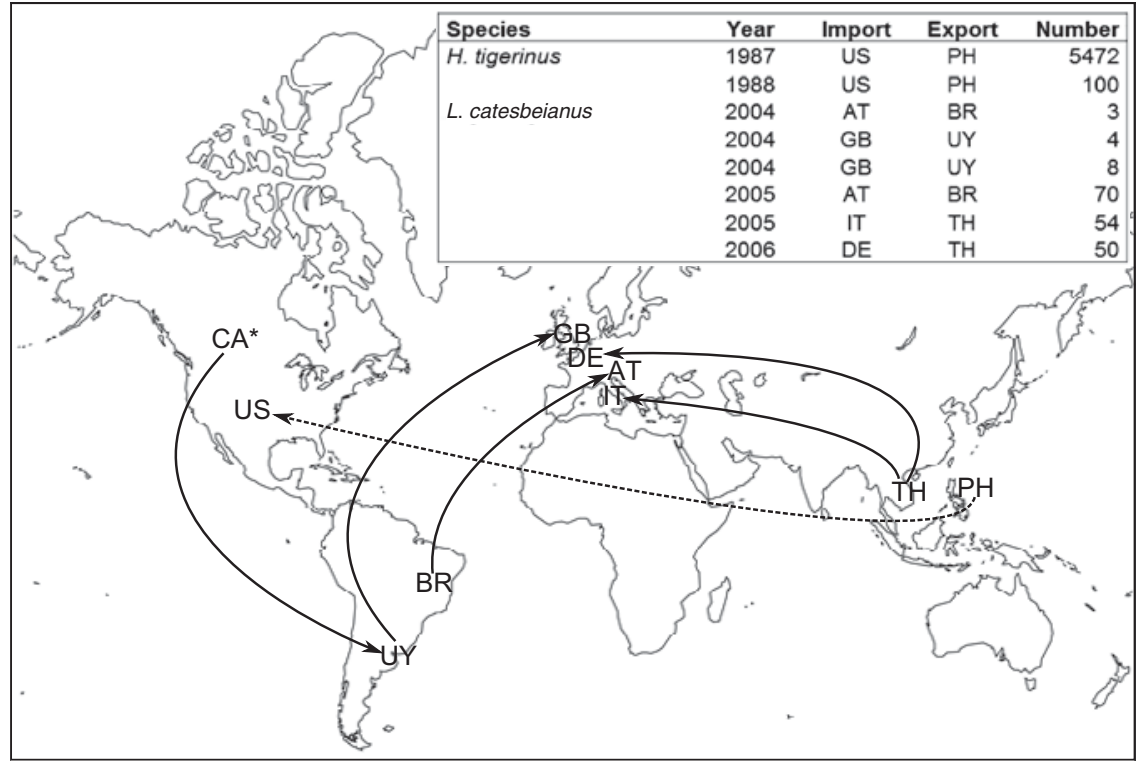

FIG. 1 The country trading links for the frog skin/leather trade reported in CITES import data (collated in August 2008) for Lithobates catesbeianus (black line) and Hoplobatrachus tigerinus (dashed line). The inset gives the levels of trade reported for both species in each bilateral trading country pair. Country codes follow CITES coding: US, United States of America; BR, Brazil; UY, Uruguay; GB, United Kingdom; DE, Germany; AT, Austria; IT, Italy; TH, Thailand; PH, Philippines; CA, Canada; *, origin country (UNEP-WCMC, 2010). species (Euphlyctis hexadactylus, Hoplobatrachus tigerinus, A. mexicanum, L. catesbeianus). These are all CITES Appendix II listed species with the exception of $L$. catesbeianus (as detailed in the methods, European Commission legislation requires the collection and reporting of trade data for this species, thus only EC-reported trade for this species is presented here). One-off trade events were included, such as the import to the USA from Italy, in 1986, of 24 pairs of shoes made from E. hexadactylus leather that originated in Singapore. Another one-off trading event was reported in 2000: five A. mexicanum items were imported to the Republic of Korea from Japan with a purpose code 'Q' (circuses and travelling exhibitions) and source code ' $C$ ' (animals bred in captivity).

The remaining trade events were all commercial activities (purpose code ' $\mathrm{T}$ ') involving the skin/leather of two frog species, $H$. tigerinus (5,572 individuals traded) and L. catesbeianus (189 individuals traded; Fig. 1). The reported trade in $H$. tigerinus was in $1987(\mathrm{n}=5,472)$ and 1988 $(\mathrm{n}=100)$, and the trade in L. catesbeianus was reported in $2004(n=15), 2005(n=124)$ and $2006(n=50$; Fig. 1$)$. There were a total of eight trade events in the two species, with five import and four export countries reported (Fig. 1). The export/import dynamics were simple one-way, bilateral events, except for Canada being the original source country of animals finally being re-exported to the UK (Fig. 1).

\section{Meat}

Since 1985 two amphibian species, E. hexadactylus and $H$. tigerinus, have been recorded in the meat trade. All trade consignments were recorded in $\mathrm{kg}$ except three events, one reported in 1990 as 160 boxes and two in 1993 as 800 cartons and five shipments (all three events involved H. tigerinus only). All trade events in amphibian meat, considered here to be legs only, were for commercial activities (' $T$ '), where the import 'purpose' had been given. However, out of a total of 178 trading events, only 80 (45\%) reported the 'source' of animals, with six source codes being cited: 'C' (captive bred; 54\%), 'W' (wild populations; 25\%), 'I' (confiscated/seized; $10 \%$ ), ' $\mathrm{F}$ ' (animals born in captivity but not fulfilling 'C' definition; 7.5\%), ' $\mathrm{O}$ ' (specimen acquired pre-convention; $1 \%$ ), plus ' $U$ ' (unknown; $2.5 \%$ ).

Trade relating to $E$. hexadactylus comprised $>2.7$ million $\mathrm{kg}$ of meat reported in just 2 years, 1985 and 1986 (Fig. 2). Posterior frog legs represent up to $40 \%$ of the total body weight (FAO, 2005), thus using a mean body weight of $129.5 \mathrm{~g}$ per animal (Hampson et al., 1998) suggests that $>52$ million frogs were imported. However, using a conversion rate of 20-50 animals per $\mathrm{kg}$ (Veith et al., 2000) suggests a range of 54-135 million frogs imported.

Nearly 24 million $\mathrm{kg}$ of $H$. tigerinus meat was traded during 1985-2006 (Fig. 3). Assuming once again that posterior frog legs represent up to $40 \%$ of total body weight and using a mean body weight of $250 \mathrm{~g}$ per animal (Daniels, 2005) suggests that 240 million frogs were imported. However, using the conversion rate of Veith et al. (2000) the total number of frogs imported is estimated to be in the range 480 million to 1.2 billion at the upper estimate level.

Therefore, using the lowest and highest estimates for both species above, the number of individual frogs imported for the meat trade ranged from a lower estimate of 292 million to an upper estimate of 1.34 billion.

Individuals (live animals)

A total of 18 genera were reported in the import trade data, totalling 482,292 individuals traded during 1978-2007 (Table 2), the main genera being Mantella (40\%), 


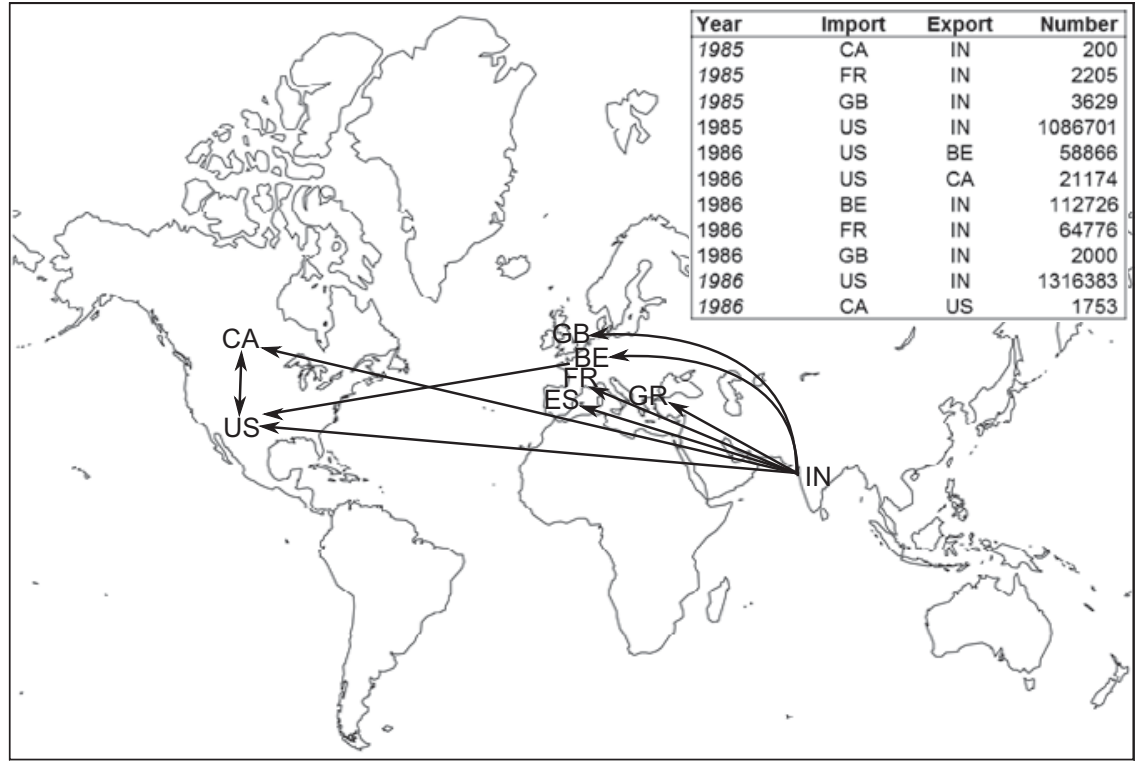

FIG. 2 The country trading links for the Euphlyctis hexadactylus meat trade as reported in CITES import data (collated in August 2008). The inset gives the levels of trade reported in each bilateral trading country pair. Country codes follow CITES coding: US, United States of America; CA, Canada; GB, United Kingdom; BE, Belgium; FR, France; ES, Spain; GR, Greece; IN, India. (UNEPWCMC, 2010).

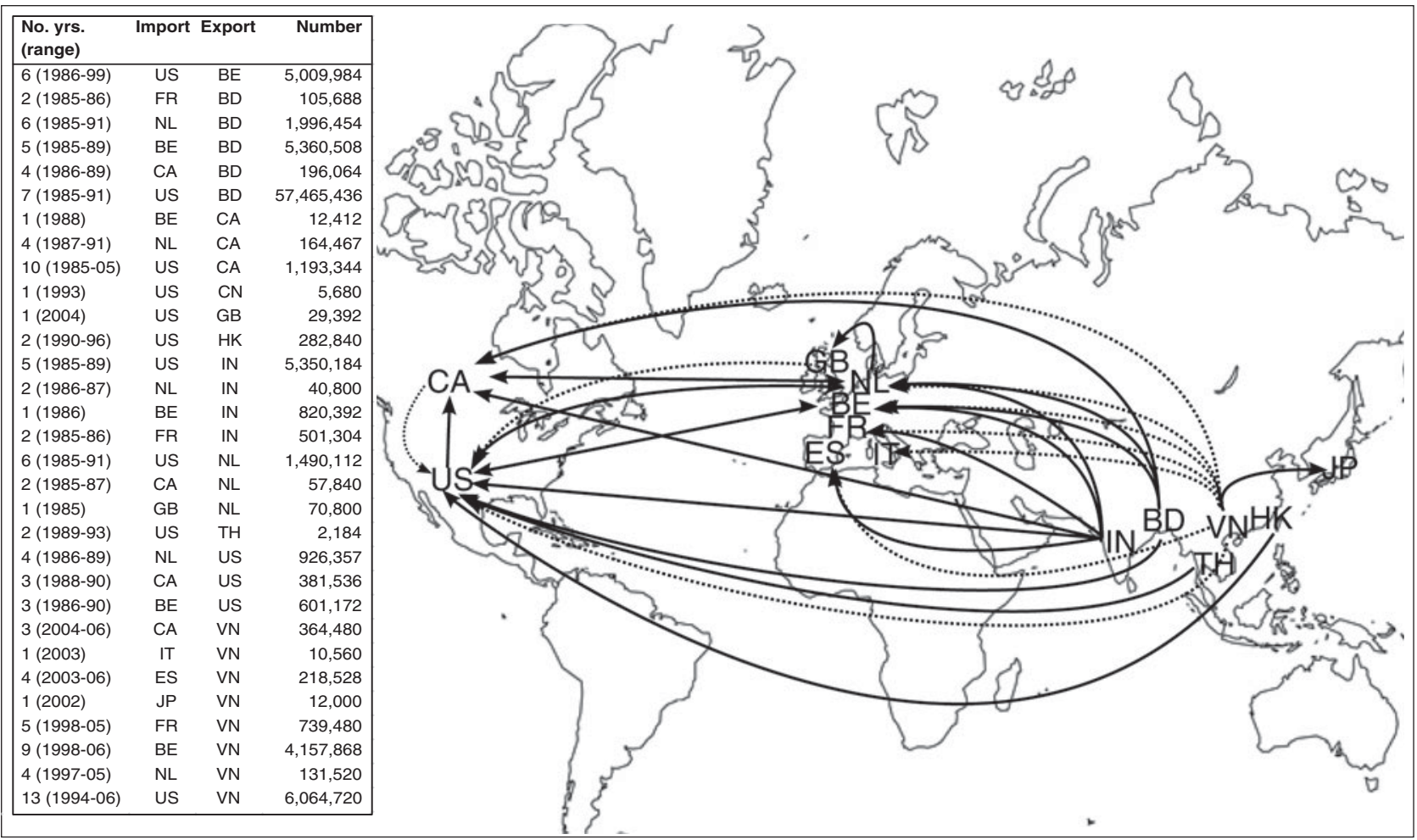

FIG. 3 The country trading links for the H. tigerinus meat trade as reported in CITES import data (collated in August 2008). Trade was divided into that conducted before 2002 (black line) and post 2002 (dotted line). The inset gives the summed level of trade reported for each bilateral trading country pair. Country codes follow CITES coding: US, United States of America; CA, Canada; GB, United Kingdom; BE, Belgium; FR, France; ES, Spain; GR, Greece; IN, India; TH, Thailand; HK, Hong Kong; VN, Vietnam; JP, Japan; BD, Bangladesh; NL, The Netherlands (UNEP-WCMC, 2010).

'Dendrobates' (31\%) and Ambystoma (22\%). Over 99\% were assigned to source codes, with most harvested from wild populations: 'W' (wild populations, $48 \%$ ), 'C' (captive bred, $37 \%$ ), 'R' (ranched, > $2 \%$ ), 'I' (confiscated/seized, $1 \%$ ), ' $F$ ' (animals born in captivity but not fulfilling ' $\mathrm{C}$ ' definition,
$1 \%$ ), 'O' (specimen acquired pre-convention, $<1 \%$ ), plus unknown sourced individuals (10\%). Over $85 \%$ of this trade was accounted for under the purpose code ' $T$ ', which indicates that commercial activity was the main driver for this type of trade, and nearly $10 \%$ was under ' $\mathrm{S}$ ' (scientific) 
TABLE 2 The 18 genera reported in the CITES import data (collated August 2008), the number of known species in each genus involved in the trade, the number of individuals traded and the percentage of the total trade accounted for by each genus (UNEP-WCMC, 2010).

\begin{tabular}{lccr}
\hline Genus & $\begin{array}{l}\text { No. of } \\
\text { spp. }\end{array}$ & $\begin{array}{l}\text { No. of } \\
\text { individuals }\end{array}$ & $\%$ \\
\hline Allobates spp. & 2 & 229 & 0 \\
Altiphrynoides malcolmi & 1 & 2 & 0 \\
Ambystoma spp. & 2 & 107,086 & 22 \\
Andrias spp. & 2 & 539 & 0 \\
Atelopus zeteki & 1 & 734 & 0 \\
Bufo spp. & 3 & 16 & 0 \\
Conraua goliath & 1 & 65 & 0 \\
Dendrobates spp. & 26 & 151,393 & 31 \\
Dyscophus spp. & 1 & 999 & 0 \\
Epipedobates spp. & 11 & 10,881 & 2 \\
Euphlyctis hexadactylus & 1 & 2,001 & 0 \\
Hoplobatrachus tigerinus & 1 & 385 & 0 \\
Mantella spp. & 14 & 193,600 & 40 \\
Nectophrynoides spp. & 2 & 6,583 & 1 \\
Nimbaphrynoides occidentalis & 1 & 368 & 0 \\
Phyllobates spp. & 5 & 4,587 & 1 \\
Lithobates catesbeianus & 1 & 485 & 0 \\
Scaphiophryne gottlebei & 1 & 2,339 & 0 \\
\hline
\end{tabular}

and c. $4 \%$ was unknown. Specifically, $32 \%$ of the total live trade of $A$. mexicanum ( $\mathrm{n}=107,059$ individuals) was reported with a scientific ('S') purpose code.

Within the 18 genera a total of 76 known species were traded on the international pet market (Table 2). The top 10 most traded species (Table 3) accounted for $78 \%$ of the amphibians destined for the international pet trade, and Mantella spp. accounted for a further $4 \%$ and would have figured in the top 10 list if it were a single known species. Six Mantella (29\%) species were recorded in the top 10 species, three 'Dendrobates' (26\%) and a single Ambystoma (22\%; Table 3). Two species (A. mexicanum and $M$. aurantiaca) are categorized on the IUCN Red List as Critically Endangered and a third species ( $M$. viridis) as Endangered (Table 3 ). Of the 76 known species reported in the international pet trade import data, 23 are categorized as Extinct $(n=1$; in 1979 a consignment of 10 Incilius periglenes was imported to the UK from an unknown export country with no other coding), Critically Endangered $(n=9)$ or Endangered $(\mathrm{n}=13)$ (Table 4).

Nearly $86 \%$ (91,612 individuals) of $A$. mexicanum were from captive-bred (' $C$ ') sources and just two consignments, in 1994, totalling 74 individuals were harvested from wild populations in Mexico and imported into the USA. However, nearly $14 \%(14,516)$ were unknown (left blank) and 764 were seized/confiscated ('I') animals. Conversely, c. 97\% of $M$. aurantiaca and $M$. viridis individuals reported in the trade were harvested from the wild.

\section{Trade dynamics}

In the export data set the first reported trade was in 1976, with one trade event of 200 live $A$. mexicanum traded between the UK and The Netherlands. In 200760 trade events were reported in 22 species, with nearly 5,000 trade events during 1976-2007. Within the import data set the first reported trade event was in 1978 , with the import into the UK from Japan of live Andrias davidianus.

In the early 1990s the trade in meat declined by nearly five orders of magnitude and low levels of trade were maintained until a slight increase was reported between 2002 and 2004 (Fig. 4). Trade in both skins and eggs was relatively low compared to that involving meat and live animals, although eggs were traded nearly every year between 1997 and 2003 (Fig. 4).

In contrast, the live trade of animals increased at a mean rate of c. $28 \%$ each year since 1978 (Fig. 4). Of the 23 species of greatest conservation concern (Table 4 ), $52 \%$ were from the three main genera reported in the trade (Fig. 5; Table 2). All of the top 10 most traded species were also included in the list of 23 species of greatest concern (Table 3). Over half the volume of trade for the entire review period occurred during the last 6 years, i.e. 2001-2007 (Fig. 5, inset) and was dominated by Mantella (Fig. 5; Table 2).

\section{Discussion}

\section{Eggs}

Overall the trade in eggs was a relatively small component of the international amphibian trade. Only two species (A. mexicanum and O. pumilio, both from the New World) were involved in this type of trade. Both of these species were in high demand. All the O. pumilio eggs traded were wild sourced, whereas A. mexicanum eggs were sourced mostly (93\%) from captive-breeding centres in the USA. Thus, these transactions can be viewed as 'neutral' in terms of conservation concern. It should also be stated that 2003 was the last year for which international trade in A. mexicanum was reported and 1999 was the last year for O. pumilio, indicating that international trade in the eggs of these two species may have ceased.

\section{Skins}

Four species were reportedly involved in the skin trade, the dominant two being $H$. tigerinus and L. catesbeianus. However, as stated in the methods, the only data available for the latter non-CITES species are those reported for international trade involving European Commission countries and must therefore be viewed as only a small proportion of the total trade in this species (Altherr et al., 2011). 
TABLE 3 The top 10 most traded amphibian species, with their IUCN Red List category (IUCN, 2012), the CITES Appendix in which they are listed, the number of individuals and the percentage of the total trade accounted for by each species, as reported in CITES import data (collated August 2008), destined for the international live trade (UNEP-WCMC, 2010).

\begin{tabular}{|c|c|c|c|c|}
\hline Species & Red List category* & CITES Appendix & No. of individuals & $\%$ \\
\hline Ambystoma mexicanum & CR & 2 & 107,059 & 22 \\
\hline Dendrobates auratus & LC & 2 & 61,839 & 13 \\
\hline Mantella aurantiaca & CR & 2 & 64,333 & 13 \\
\hline Oophaga pumilio & $\mathrm{LC}$ & 2 & 33,429 & 7 \\
\hline Dendrobates tinctorius & LC & 2 & 30,842 & 6 \\
\hline Mantella madagascariensis & VU & 2 & 24,131 & 5 \\
\hline Mantella pulchra & $\mathrm{VU}$ & 2 & 15,367 & 3 \\
\hline Mantella betsileo & LC & 2 & 13,972 & 3 \\
\hline Mantella viridis & $\mathrm{EN}$ & 2 & 11,675 & 2 \\
\hline Mantella laevigata & NT & 2 & 11,962 & 2 \\
\hline Mantella spp. & & & 21,046 & 4 \\
\hline
\end{tabular}

${ }^{\star}$ LC, Least Concern; VU, Vulnerable; EN, Endangered; CR, Critically Endangered

TABLE 4 The 23 species reported in CITES import data in the international pet trade that were also categorized as Extinct, Critically Endangered or Endangered on the IUCN Red List (in alphabetical order by category; IUCN, 2012). The Latin name used on the IUCN Red List has been provided if it is different from that used by CITES, with the common names, if available, used on the IUCN Red List (UNEPWCMC, 2010).

\begin{tabular}{|c|c|c|c|c|}
\hline $\begin{array}{l}\text { Species name } \\
\text { (used by CITES) }\end{array}$ & $\begin{array}{l}\text { No. of } \\
\text { individuals }\end{array}$ & $\begin{array}{l}\text { Red List } \\
\text { category }^{\star}\end{array}$ & $\begin{array}{l}\text { Species name } \\
\text { (used by IUCN) }\end{array}$ & $\begin{array}{l}\text { Common name } \\
\text { (used by IUCN) }\end{array}$ \\
\hline Bufo periglenes & 10 & EX & Incilius periglenes & Golden toad \\
\hline Ambystoma dumerilii & 18 & $\mathrm{CR}$ & & Achoque \\
\hline Ambystoma mexicanum & 107,059 & $\mathrm{CR}$ & & Axolotl \\
\hline Andrias davidianus & 378 & $\mathrm{CR}$ & & Chinese giant salamander \\
\hline Atelopus zeteki & 734 & $\mathrm{CR}$ & & Golden arrow poison frog \\
\hline Dendrobates lehmanni & 54 & $\mathrm{CR}$ & Oophaga lehmanni & Red-banded poison frog \\
\hline Mantella aurantiaca & 64,333 & $\mathrm{CR}$ & & Golden mantella \\
\hline Mantella milotympanum & 5,215 & $\mathrm{CR}$ & & Black-eared mantella \\
\hline Nectophrynoides asperginis & 4 & $\mathrm{CR}$ & & Kihansi spray toad \\
\hline Nimbaphrynoides occidentalis & 368 & $\mathrm{CR}$ & & \\
\hline Altiphrynoides malcolmi & 2 & EN & & \\
\hline Conraua goliath & 65 & EN & & \\
\hline Dendrobates arboreus & 42 & $\mathrm{EN}$ & Oophaga arborea & Polkadot poison frog \\
\hline Dendrobates mysteriosus & 7 & EN & Excitobates mysteriosus & Maranon poison frog \\
\hline Dendrobates speciosus & 31 & EN & Oophaga speciosa & Splendid poison frog \\
\hline Epipedobates tricolor & 4,128 & EN & & Rana tricolour ecuatoriana \\
\hline Mantella bernhardi & 1,817 & EN & & Bernhard's mantella \\
\hline Mantella crocea & 6,789 & EN & & Yellow mantella \\
\hline Mantella expectata & 8,550 & EN & & Blue-legged mantella \\
\hline Mantella viridis & 11,675 & $\mathrm{EN}$ & & Green mantella \\
\hline Phyllobates terribilis & 979 & EN & & Golden poison frog \\
\hline Phyllobates vittatus & 2,121 & EN & & Golfodulcean poison frog \\
\hline Scaphiophryne gottlebei & 2,339 & EN & & \\
\hline
\end{tabular}

${ }^{*}$ EX, Extinct; EN, Endangered; CR, Critically Endangered

The trade events for the other two species involved extremely small numbers and appeared to be novelties but the trade in the dominant two species was for commercial purposes and occurred in two short periods of time (2 years for H. tigerinus and 3 years for L. catesbeianus). The trade in $H$. tigerinus appears to have been a one-off, whereas the trade in $L$. catesbeianus was more recent and possibly continues. However, as L. catesbeianus is not listed by
CITES, there is no requirement for CITES permits internationally and consequently there is no means of recording and reporting any trade in this species. However, the European Commission has introduced legislation that requires member states to report any trade conducted in this species on their CITES report submissions because of potential negative impacts on native fauna (Altherr et al., 2011). 


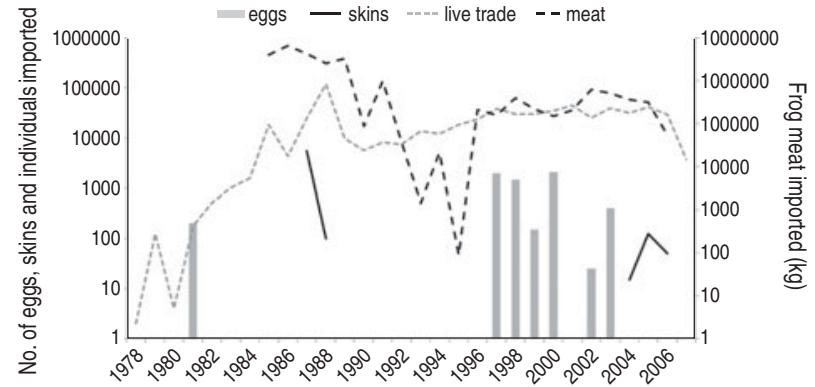

FIG. 4 The trends (on a logarithmic scale) for each of the trade groups reported in the CITES import data for 1976-2007 (UNEP-WCMC, 2010).

L. catesbeianus has been introduced to locations worldwide as a biocontrol agent to support farming and as a food source $(\mathrm{FAO}, 2005)$. Although the species is categorized as Least Concern on the IUCN Red List, its listing as one of the top 100 world's worst invaders by the IUCN's Invasion Species Specialist Group raises conservation concerns. These concerns are based on expanding populations of the species where it has been introduced and the negative wider impacts it can have, such as on ecosystem change, disease transmission, competition and predation (Crayon, 2009). This raises an interesting alternative reason for listing a species on CITES. Rather than the issue being centred on the trade having a non-detrimental finding (i.e. the trade does not threaten the survival of the species) as reported by the Management Authority, a rationale for listing and monitoring a species could be based on the known negative impacts, either direct or indirect, that a species can have on an importing country's native fauna. Whilst such a basis is not the focus of CITES per se, it could nevertheless be the best mechanism for capturing and managing such data.

\section{Meat}

Previous studies have cited high economic values for the trade in amphibian meat; for example, USD 40 million (Gratwicke et al., 2010). However, using the 2006 price of USD 4.17 (imported) per kg (Gratwicke et al., 2010), the total value for the meat trade reported within this study period was estimated at > USD 111 million. Over 95\% of this trade was in just one species (H. tigerinus), which had two trade phases. It was traded firstly from Bangladesh, up to $1992 / 1993$, then this was replaced by trade from Vietnam. Officially, Bangladesh banned exports of frogs' legs in 1989, as did India in 1987; however, the actual export of frogs only ceased following a proposal to CITES Conference of the Parties 8 (Altherr et al., 2011). The numbers of animals involved in this type of trade were extremely high and although harvesting from the wild contributed substantially to these numbers, the extraction of individuals for meat received limited conservation attention (Warkentin et al., 2009), especially regarding the two species listed here.
Recently, much conservation interest has focused on the potential spread of disease by amphibians in the meat trade, specifically chytridiomycosis, caused by the fungus Batrachochytrium dendrobatidis (Daszak et al., 2007; Schloegel et al., 2009a,b; Gratwicke et al., 2010). However, the UN Food and Agriculture Organization (FAO), which promotes the farming of frogs and has stated that the vast majority of trade is in frozen frogs' legs, a statement supported by Warkentin et al. (2009), describes practices that potentially negate disease transmission within this type of trade (Crayon, 2009). The FAO provides guidance to farmers on how to humanely dispatch a frog, remove the skin, wash the legs in chlorinated water and freeze the legs at $\sim 15 \pm 2{ }^{\circ} \mathrm{C}$ for storage and transportation (Crayon, 2009), all of which potentially removes or at least reduces the possible threat of disease transmission via this type of trade.

An important aspect of the meat trade that was beyond the scope of this review is the demand for frogs as a protein source by local people. In this situation the species involved could be very different to those traded internationally, such as witnessed in Madagascar (Jenkins et al., 2009), and could possibly be species of high conservation concern.

\section{Individuals (live animals)}

Although low relative to the meat trade, the trade in live animals destined for the international pet market attracts much conservation attention. A total of 18 genera were reported in the trade within the study period, with three dominating the live trade: Mantella, 'Dendrobates' and Ambystoma. In the case of Ambystoma 68\% was for the pet trade and $32 \%$ for scientific purposes. That $78 \%$ of the total live trade was accounted for by just 10 species and the majority of individuals were harvested from wild populations indicates why much attention continues to be afforded to these species, and will be until such a time that sustainable harvesting criteria can be met (Carpenter et al., 2007). Over a third of individuals were sourced from captive-breeding centres; however, it is probable that captive-bred individuals account for a higher proportion of live-traded individuals, taking into account the demands of internal markets. For example, both 'Dendrobates' and Mantella are bred commercially in large numbers in the EU and USA and captivebred animals now probably meet most of the commercial demand within those areas (R. Griffiths, pers. obs.). Where these individuals are supplied to meet demands from within the same country, CITES permits are not required, resulting in these individuals being omitted from any such review. However, from a conservation perspective, priority should be given to wild populations and their habitats. Therefore, the data presented here should be viewed as a proxy for the levels of extraction from wild populations. CITES has previously raised concerns over the non-detrimental finding calculations reported for Mantella by Madagascar 


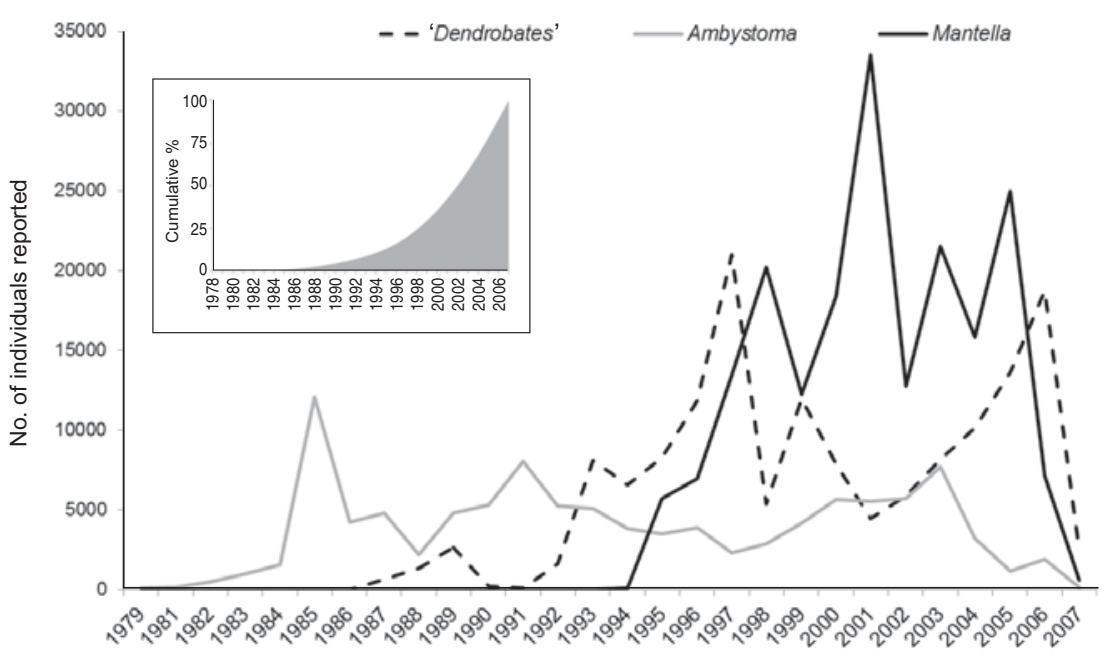

FIG. 5 The trends in trade of 'Dendrobates', Ambystoma and Mantella that were reported in the import trade in the CITES data for 1976-2007. The inset gives the cumulative percentage indicating the rate of growth of the international live trade for all species reported in the import data, for the same period (UNEP-WCMC, 2010).
(CITES, 2011; UNEP-WCMC, 2012), highlighting the need for quota calculations to be checked for at least the top 10 species.

Reviewing the number of species traded within each genus ('Dendrobates', 26 species and 151,393 individuals; Ambystoma, two species and 107,086 individuals; Mantella, 14 species and 193,600 individuals) and the number of years for which trade is reported indicates that Mantella is the genus of most concern, with $>12,000$ individuals on average traded each year. This is followed by 'Dendrobates', with 6,882 individuals traded per year. Whilst there is much price variation between species, Tapley et al. (2011) reported prices for Mantella, 'Dendrobates' and Ambystoma species. Adjusting these for inflation provides a mean 2012 real-time price of USD 59.50 each for Mantella, USD 99.21 for 'Dendrobates' and USD 45.78 for Ambystoma. Based on these mean prices the combined annual trade of these three genera were worth $>$ USD 11.5 million.

\section{Trade dynamics}

By analyzing the import data set the values presented here are more conservative than those that would have been produced using the export data. They are also considered more accurate levels of the actual trade conducted, being based on the numbers traded rather than permits issued and more robust management and reporting by import countries (Harwood, 1999; Carpenter, 2003).

The live trade for the global pet market is increasing, with $>60 \%$ of the total live trade recorded after 1996 . This is in contrast to the international meat trade in CITES-listed species, which is decreasing. Gratwicke et al. (2010) and Schloegel et al. (2009a) reported that international trade for meat from species not listed by CITES remains strong. Trade dynamics are also affected by changes in the status of a species, such as a species being moved from CITES
Appendix II to Appendix I, a species being added to Appendix II or, as with L. catesbeianus, when changes in regional or national legislation result in trade being captured and reported. It is unclear whether there was an increasing trend in the trade of either skins or eggs during the study period as the trade events reported were relatively uncommon and resulted in no clear trend.

The spatial dynamics of the trade types were on the whole simplistic, bilateral arrangements between countries. Where this pattern differed it was because products, such as skins, required tanning in one country and craftsmanship in another to change the leather into a product, or because of historical relationships, such as consignments going to traditional colonial countries before then being re-exported to other countries. However, these historical, three-tier structures were often replaced by direct trading between the supply and demand countries where transport routes permitted. Personal interactions, such as an exporter changing the location of their business and their knowledge of the trade operations, also play an important part in these structures. Changes in spatial dynamics because of these factors would often be driven by national and/or international changes in legislation that caused an exporter to change location, often to improve their income but also to circumvent changes in national legislation or governance (A. Carpenter, pers. obs.).

This study raises several issues for future research. For example, detailed valorization of the trade is required at the species level across all stakeholders involved, especially within the supply country and specifically at the collection sites, to identify the potential benefits to conservation. Furthermore, trade data are important for reviews of CITES-listed species and should be regularly compared with harvest quotas for sustainability. The study also highlights the need for a mechanism for collecting trade data on species not listed by CITES. This would facilitate more accurate calculations of the value of wildlife resources 
from a country and also provide a way to monitor species that may be considered undesirable alien species. Lastly, in regard to the potential benefits to conservation arising from the trade in wildlife, this study has indicated that there are certain windows of opportunity. Further research is needed to investigate how market dynamics influence trade, conservation and sustainable use (Carpenter et al., 2004, 2005). With an increasing number of species being bred ex situ on a commercial scale to meet the demands of trade, it will be useful to monitor how such activities influence supply and demand, price structures and the cost-effectiveness of continuing to collect animals from the wild.

\section{Acknowledgements}

The authors are very grateful to Dr David Roberts and two anonymous reviewers for their helpful and constructive comments.

\section{References}

Altherr, S., Goyenechea, A., Schubert, D. (2011) Canapés to Extinction - the International Trade in Frogs' Legs and its Ecological Impact. A report by Pro Wildlife, Defenders of Wildlife and Animal Welfare Institute, Munich, Germany, and Washington, DC, USA.

Andreone, F., Cadle, J.E., Cox, N., Glaw, F., Nussbaum, R.A., Raxworthy, C.J. et al. (2005) A species review of amphibian extinction risks in Madagascar: results from the Global Amphibian Assessment. Conservation Biology, 19, 1790-1802.

Andreone, F., Carpenter, A.I., Cox, N., du Preez, L., Freeman, K., Furrer, S. et al. (2008) The challenge of conserving amphibian megadiversity in Madagascar. PLoS Biology, 6, e118, 0943-0946.

Bielby, J., Cooper, N., Cunningham, A.A., Garner, T.W.J. \& Purvis, A. (2008) Predicting susceptibility to future declines in the world's frogs. Conservation Letters, 1, 82-90.

Brooks, T., Bakarr, M., Boucher, T., Fonseca, G.A.B., Hilton-Taylor, C., Hoekstra, J.M. et al. (2007) Environmental and historical constraints on global patterns of amphibian richness. Proceedings of the Royal Society B, 274, 1167-1173.

Burgess, N.D., Butynski, T.M., Cordeiro, N.J., Doggart, N.H., FJeldSÅ, J., Howell, K.M. et al. (2007) The biological importance of the Eastern Arc Mountains of Tanzania and Kenya. Biological Conservation, 134, 209-231.

Carpenter, A.I. (2003) The ecology and exploitation of chameleons in Madagascar. PhD thesis, University of East Anglia, Norwich, UK.

Carpenter, A.I., Dublin, H., Lau, M., Syed, G., McKay, J.E. \& Moore, R.D. (2007) Over-harvesting. In Amphibian Conservation Action Plan (eds C. Gascon, J. Collins, R.D. Moore, D.R. Church, J.E. McKay \& J.R. Mendelson), pp. 26-31.

IUCN/SSC Amphibian Specialist Group, Gland, Switzerland and Cambridge, UK.

Carpenter, A.I. \& Robson, O. (2008) Madagascan amphibians as a wildlife resource and their potential as a conservation tool: species and numbers exported, revenue generation and bio-economic models to explore conservation benefits. In Conservation Strategy for the Amphibians of Madagascar Proceedings (ed. F. Andreone), pp. 357-376. Monografie XLV, Museo Regionale di Scienze Naturali, Torino, Italy.

Carpenter, A.I., Robson, O., Rowcliffe, M. \& Watkinson, A.R. (2005) The impacts of international and national governance on a traded resource: a case study of Madagascar and its chameleon trade. Biological Conservation, 123, 279-287.

Carpenter, A.I., Rowcliffe, M. \& Watkinson, A.R. (2004) The dynamics of the global trade in chameleons. Biological Conservation, 120, 295-305.

CITES (2004) A Guide to Interpreting Outputs from the CITES Trade Database. Http://www.cites.org/common/resources/ TradeDatabaseGuide.pdf [accessed 30 August 2013].

CITES (2009a) Resolution Conf. 12.11 (Rev. CoP15): Standard Nomenclature. Http://www.cites.org/sites/default/files/eng/res/all/ 12/E12-11R15.pdf [accessed 30 August 2013].

CITES (2009b) Glossary. Http://www.cites.org/eng/resources/terms/ index.php [accessed January 2009].

CITES (2010) A Guide to Using the CITES Trade Database, v. 7. Http://www.unep-wcmc-apps.org/citestrade/docs/ CITESTradeDatabaseGuide_v7.pdf [accessed 10 July 2013].

CITES (2011) Review of Significant Trade in Specimens of Appendix-II Species: Species Selected Following CoP13. Report to the 25th meeting of the Animals Committee, Geneva, Switzerland. Http://www.cites.org/eng/com/ac/25/E25-09-03.pdf [accessed 27 August 2012].

Corey, S.J. \& Waite, T.A. (2008) Phylogenetic autocorrelation of extinction threat in globally imperilled amphibians. Diversity and Distributions, 14, 614-629.

Crayon, J. (2009) Global Invasive Species Database: Lithobates catesbeianus. Http://www.issg.org/database/welcome/ [accessed September 2010].

D Aniels, R.J.R. (2005) Amphibians of Peninsular India. Universities Press India, Hyderabad, India.

Daszak, P., Lips, K., Alford, R., Carey, C., Collins, J.P., Cunningham, A. et al. (2007) Infectious diseases. In Amphibian Conservation Action Plan (eds C. Gascon, J. Collins, R.D. Moore, D.R. Church, J.E. McKay \& J.R. Mendelson), pp. 21-25. IUCN/SSC Amphibian Specialist Group, Gland, Switzerland and Cambridge, UK.

FaO (Food and Agriculture Organization of the United Nations) (2005) Cultured Aquatic Species Information Programme. Rana catesbeiana. Cultured Aquatic Species Information Programme. FAO Fisheries and Aquaculture Department [online]. Rome, Italy. Http://www.fao.org/fishery/ culturedspecies/Rana_catesbeiana/en [accessed 27 August 2012].

Gascon, C., Collins, J.P., Moore, R.D., Church, D.R., McKay, J.E. \& Mendelson, J.R. (eds) (2007) Amphibian Conservation Action Plan. IUCN/SSC Amphibian Specialist Group, Gland, Switzerland and Cambridge, UK.

Gibbons, J.W., Scott, D.E., Ryant, T.J., Buhlmann, K.A., Tuberville, T.D., Metts, B.S. et al. (2000) The global decline of reptiles, Déjà Vu Amphibians. BioScience, 50, 653-666.

Global Amphibian Assessment (2008) Amphibians on the IUCN Red List. Http://www.iucnredlist.org/amphibians [accessed January 2009].

Gratwicke, B., Evans, M.J., Jenkins, P.T., Kusrini, M.D., Moore, R.D., SEvin, J. \& Wildt, D.E. (2010) Is the international frog legs trade a potential vector for deadly amphibian pathogens? Frontiers in Ecology and the Environment, $8,438-442$.

Hampson, K., Sanders, K., Bennett, D., Anderson, M. (1998) Frogs of Coorg, Karnataka, India: Aberdeen University Western Ghats Project 1998. Viper Press, UK. 
Harwood, J. (1999) A Report on Annual Reports Submitted by the Parties to CITES. World Conservation Monitoring Centre, Cambridge, UK.

Jenkins, R.K., Rabearivelo, A., Andre, C.T., Randrianavelona, R. \& Randrianantoandro, C. (2009) The harvest of endemic amphibians for food in eastern Madagascar. Tropical Conservation Science, 2, 25-33.

OzA, G.M. (1990) Ecological effects of the frog's legs trade. Environmentalist, 10, 39-42.

Rosser, A., Haywood, M. \& Harris, D. (2001) CITES: A Conservation Tool. IUCN Species Survival Commission, Cambridge, UK.

Schlaepfer, P.M., Hoover, C. \& Dodd, C.K. (2005) Challenges in evaluating the impact of the trade in amphibians and reptiles on wild populations. BioScience, 55, 256-264.

Schloegel, L.M., Ferreira, C.M., James, T.Y., Hipolito, M., Longcore, J.E., Hyatt, D. et al. (2009a) The North American bullfrog as a reservoir for the spread of Batrachochytrium dendrobatidis in Brazil. Animal Conservation, 13, 53-61.

Schloegel, L.M., Picco, A., Kilpatrick, A.M., Davies, A.J., Hyatt, A.D. \& Daszak, P. (2009b) First definitive evidence of Batrachochytrium dendrobatidis and ranavirus infections in frogs imported into the USA for human consumption. Biological Conservation, 142, 1420-1426.

STUART, S. (2007) The continuing needs for assessments: making the global amphibian assessment an ongoing process. In Amphibian Conservation Action Plan (eds C. Gascon, J. Collins, R.D. Moore, D.R. Church, J.E. McKay \& J.R. Mendelson), pp. 43-44. IUCN/SSC Amphibian Specialist Group, Gland, Switzerland and Cambridge, UK.

Stuart, S.N., Chanson, J.S., Cox, N.A., Young, B.E., Rodrigues, A.S.L., Fischman, D.L. \& Waller, R.W. (2004) Status and trends of amphibian declines and extinctions worldwide. Science, 306, 1783-1786.

Tapley, B., Griffiths, R.A., Bride, I. (2011) Dynamics of the trade in reptiles and amphibians within the
United Kingdom over a ten-year period. Herpetological Journal,

21, 27-34.

UneP-WCMC (United Nations Environment ProgrammeWorld Conservation Monitoring Centre) (2010) CiTES Trade Database. Http://www.unep-wcmc-apps.org/citestrade/ [accessed 30 August 2013].

UneP-WCMC (United Nations Environment Programme-

World Conservation Monitoring Centre) (2012) Review of Significant Trade: Species Selected by the CITES Animals Committee Following $\mathrm{CoP}_{14}$ and Retained in the Review Following AC25. Http:// www.cites.org/eng/com/ac/26/E26-12-02-A.pdf [accessed 27 August 2012].

Veith, M., Kosuch, J., Feldmann, R., Martens, H. \& Seitz, A. (2000) A test for correct species declaration of frog leg imports from Indonesia into the European Union. Biodiversity and Conservation, 9, 333-341.

Wake, D.B, \& Vredenberg, V.T. (2008) Are we in the midst of the sixth mass extinction? A view from the world of amphibians. Proceedings of the National Academy of Sciences of the United States of America, 105, 11466-11473.

Warkentin, I.G., Bickford, D., Sodhi, N.S. \& Bradshaw, C. (2009) Eating frogs to extinction. Conservation Biology, 23 1056-1059.

\section{Biographical sketches}

Angus CARPENTER is a conservation biologist and a member of the IUCN SSC Amphibian Specialist Group. Franco Andreone is curator of zoology at the Museo Regionale di Scienze Naturali and current president of the International Society for the Study and Conservation of Amphibians. Robin Moore is Program Officer IUCN SSC Amphibian Specialist Group. RICHARD A. Griffiths is Director of the Durrell Institute of Conservation and Ecology and works on the conservation of amphibians and reptiles. 